\title{
Winescape: Local Reinhabitation Narratives (The Case of Zielona Góra)
}

There is probably no story about Zielona Góra that neglects to mention the city's wine tradition. The grapevine, grown in the area of the original settlement since the twelfth century, is so closely tied with the history of the place that in the imaginative geography of the Vineyard (as Zielona Góra is rightfully called), enographic motifs come to the fore as the landmarks of literary topography.

Literary works about the Zielona Góra winemaking, the oldest of which (the poem "Ejsagoge" by Simon Grisbeck) comes from the beginning of the seventeenth century, envisage grapevines as an integral part of the city, talk about its cultivation and praise the family-owned vineyards. They also show Grünberg, as Zielona Góra was called until $1945,{ }^{1}$ as an Arcadian land of wine and joy. This is how Paul Petras, one of the most famous pre-war authors describes it in the poem "Kennst du die Stadt" (Do you know this city?) from 1925, which is an allusion to the famous song "Do you know this country" by Johann Wolfgang

1 It should be noted, that Zielona Góra is located on the so-called Recovered Territories (the territory of the former Free City of Danzig and the part of pre-war Germany that became part of Poland after World War II) and the German past is an element of everyday existence of Zielona Gora's inhabitants, hence the references to winemaking and its German history of place present an important component of their identity. 
Goethe. Petras paints the image of "a city in a beautiful Silesian country / Which is dressed in a gentle spring wreath of grapevines" (134).

Before the war, however, satirical works about the local wine, regarded as an exceptionally sour and tasteless beverage, enjoyed more popularity than idyllic descriptions. The grünberger, famous all over Germany, inspired satirical poems, feast songs and plays, including the one-act farce performed in 1834 on the stage of the Warmbrunn Theater (in today's Cieplice-Zdrój), Karl von Holtei's 33 minutes. That piece, as well as the satirical poem by Johannes Trojan, written half a century later, Die 88er Weine (Vintage 1888 wines) did the most to popularize the wine produced in Zielona Góra.

Despite the fact that after 1945 the local drink was no longer produced and the local vineyards deteriorated considerably, the subject of wine penetrated into Polish post-war literature. The earliest forerunner of the motif can be found in the legends that make up the city's foundation story. One of them, entitled Devil, wine and knight, says that Zielona Góra wine came to being as a result of a pact between a knight and the devil (Devil, wine and knight 189-192).

In later years, the enographic motif appeared mainly in the context of the Grape Harvest Festival, the only wine tradition that has continued uninterruptedly after the war, although its form was different from Weinlesefest (Germ. "The wine harvest festival"). Every year in September locals crowd to see the colorful procession; however, this was just an external reference to winemaking activities. ${ }^{2}$ When the vineyards became "only an embellishment of the urban landscape" (Kajan 332), as Tadeusz Kajan wrote in 1960, images of a vine or a grape cluster appeared in Zielona Góra literary works (mainly in poetry) as an ornament which captures the local flavor of the town. This is the case with the poems of Janusz Koniusz ("W winnicach" [In the vineyards]) and Henryk Szylkin ("Zielonogórskie winnice" [Zielona Góra vineyards]), where the grapes decorate the landscape, the city's emblem. Such texts began to appear in greater numbers after 1965, inspired by the grape harvest competition announced annually by the editors of the Nadodrze magazine from Zielona Góra.

By comparison, prose works that have been published since the beginning of the 21st century, mainly Niewinne miasto [An innocent city] (2003) by Czesław Markiewicz, Grünberg (2012) by Krzysztof Fedorowicz, Mniejsza epopeja (A minor epic) (2014) Marek Jurgoński, Wendyjska Winnica: Winne miasto (Vendian Vineyard: Wine City) (2019) by Zofia Mąkosa and the collection of

2 The celebration of the wine festival went much further than German practices, turning the wine harvest festival into a festival of "folk homeland" and included the official propaganda of success. 
essays Enografia mistyczna (Mystical enography) (2013) by Mirosław Kuleba, ${ }^{3}$ is a new literary and cultural phenomenon. ${ }^{4}$ The novelty lies mainly in the fact that, unlike in earlier literature, these works not only summon the motifs of wine, grapes and grapevine, but also operationalize them as an interpreter of phenomena, situations and historical and social processes, in particular those processes that occur between a person/community and a place.

In each of the above-mentioned works, Zielona Góra is both the background of the events and their participant. Niewinne miasto is an attempt to face the past, which was overshadowed by the so-called events in Zielona Góra on May 30, 1960 (fights with the Militia for the Parish House). The protagonist of the novel tries to discover the secret of those events and thus regain his bond with his childhood city. The same theme organizes the plot of the Mniejsza epopeja. In Jurgoński's poem, however, it is not so much about solving the mystery of the so-called events of Zielona Góra, but about the work of memory-the image of the city becomes an integral element of the autobiographical experience. The novels Grünberg and Winne Miasto are belated founding stories; their plot covers the Polish beginnings of Zielona Góra and tells about the traumatic events that happened right after the war. Kuleba's essays, on the other hand, describe various moments of the city's wine history and mixed place's images from centuries ago, German past and Polish history.

All these works are "collective texts" as understood by Astrid Erll, i.e. those which, by referring to symbolic resources, by creating and reinforcing myths, as well as transmitting patterns typical of local culture, function within the culture of memory of a place (Erll 234). In the case of Zielona Góra prose, it is about enographic patterns created in line with changes in the framework of memory under way since the 199os under the influence of social, internal and external political factors; their source and reference point is winescape.

The aim of this article is to show how, in reference to the city's German past, the newest literary works connected to Zielona Góra project the winescape and as local reinhabitation narratives reactivate place and its cultural and ecological possibilities.

3 When quoting the above-mentioned works, I will use the following abbreviations: WN - Winne miasto, NM - Niewinne miasto, G - Grüberg, ME - Mniejsza epopeja; $E M$ - Enografia mistyczna. With the page number given in parentheses.

4 Since 1989 local writers became more interested in the German past of Zielona Góra. They started to describe this town as the palimpsest in order to present multiple cultures and as the sign of Polish-German cultural heritage. See Gieba 2015; 2016; 2017; 2019; Mikołajczak 2014; 2016a; 2016b. 
The concept of winescape derives from marketing research on the so-called servicescape: the provision of services based on goods sourced from the natural environment and in its original meaning concerns the functioning of the "wine industry" in a region (Alampi Sottini, Barbierato, Bernetti, Capecchi, Fabbrizzi, Menhini 127). For this reason, winescape is chiefly of interest to marketing and economics, as well as to multidisciplinary and interdisciplinary tourism research. Within these disciplines, it is treated as a construct created through the interaction of a number of elements: places connected with the cultivation and exploitation of wine (vineyards, wineries and other stakeholders involved in wine production), the natural landscape and location of the land, the community living in the region and its traditions, as well as architecture and cultural artifacts. So understood, winescape can also exert an aesthetic effect through sensory perception (1), expression of feelings and emotions allied with winescape (2), the reception of symptoms (when the elements of the landscape become a symptom of other phenomena) (3) and symbolic reception (4). An additional, supra-level of reception, is determined by the perspective of cultural geography, according to which the "wine landscape" - perceived differently by different groups of people-is a derivative of the observations of the visitors and the residents of the wine region (Johnson, Bruver 77).

When adapting the notion of winescape to literary research, we should take into account the latter approach and recall the category of cultural landscape, emerging from geographic and cultural frameworks and gaining more and more popularity in contemporary humanities. As a hybrid concept, the "wine landscape" fits perfectly into landscape studies, in which cultural phenomena are examined in close association with civilization and nature. Suffice it to note that "none of the agricultural processes has been so deeply embedded in culture and symbolism as winemaking. At the same time, no branch of culture contains so many references to natural processes" (Leszkowicz-Baczyński 238).

Winemaking is also associated with another characteristic of the cultural landscape, one which combines many disparate types of human activity. Timothy Ingold, who stresses this aspect in his research on cultural landscape, writes that the landscape, co-created both by people and the environment, culture and the biosphere, is a kind a practiced space, i.e. one experienced and created by the community which for generations has been undertaking "tasks" inscribed in the landscape. As such it is a dynamic construct, subject to constant dialectics and structuring, which interactively shapes the relationship between the subject and the world (Ingold 141-157). It is also important for this discussion that this taskscape, as the researcher calls it, is narrative in 
nature: "[a] landscape tells-or rather is-a story. It enfolds the lives and times of predecessors who, over the generations, have moved around in it and played their part in its formation" (Ingold 142).

In the study of local literature, it is also worth considering another approach which combines naturalistic perception of the landscape as the external background of human activity with a cultural approach, envisioning landscape as a specific, symbolic and cognitive arrangement of space, while originating from the same Heideggerian idea of dwelling as Ingold's theory. What I have in mind is Christopher Tilley's phenomenological concept which, unlike other cultural ways of understanding the landscape, emphasizes relationships with the local community. Tilley is concerned with the social relations encoded in the landscape and the ways in which the properties of the landscape can be used to create meaning for the local community. In his book, A Phenomenology of Landscape, we read that

The spirit of a place may be held to reside in a landscape. Familiarity with the land, being able to read and decode its signs allows individuals to know 'how to go on' at a practical level of consciousness or one that may be discursively formulated. People routinely draw on their stocks of knowledge of the landscape and the locales in which they act to give meaning, assurance and significance to their lives. (Tilley 26)

In light of the concepts cited, the winescape encountered in literary texts stands out as a particular kind of cultural landscape: one which-by combining natural topography and biosphere with civilization and culture milieu of a wine region and with existential experience embedded in the local space-encodes patterns of action using literary meanings themed around wine, grapes and grapevine. The enographic narratives which create the local "environment of memory" that embody the past, present and future emerge with the participation of these meanings. If the landscape "is a cultural code for living, an anonymous 'text' to be read and interpreted, a writing pad for inscription" (Tilley 421), the enographic narratives have the status of "metahistory": they "narrate" the landscape.

The concept of landscape, unlike the concept of place, which stresses difference and singularity, is, as the author of A Phenomenology of Landscape writes, holistic, oriented toward inclusion rather than exclusion and toward relationships 
(Tilley 422). In the newest prose from Zielona Góra, the inclusive and relational dimension of the winescape manifests itself in the interference of the world of plants and humans, and in the interpenetration of temporal modes. The overlapping images of the past, present, and future of the city, along with the bio- and sociosphere which fills it, create a dynamic structure, for which the organicist vision of culture/nature is a reference. Let us start with the image outlined in the novel Winne miasto by Mąkosa:

Vine bushes can be found at every turn, outside the city and inside it. Even on buildings, above windows and doors, snake-like shoots wind fancifully, climb upwards, crawl as thick wreaths or form garlands. Ripe, heavy grapes peak out from behind the leaves, which I'm sure anyone would be tempted to eat if not for the fact that they were made of hard plaster. Grapevines and the city are an inseparable organism. It is difficult to imagine that one could exist without the other. (WM 109)

The phantasy shown here, based on the symbiotic coexistence of the world of plants and people, is premised on the image of the city recorded in old chronicles. Markiewicz, who refers to these accounts in his novel Niewinne miasto (The Innocent City), says that "many years ago Zielona Góra was the northernmost town in Europe, where grapevine was grown on an industrial scale" (NM 17). Fedorowicz supplements this view in the following way: "According to an old truth, the best wine is born at the northern limit of varietal occurrence" (G 54), he writes in the novel Grünberg, calling the eponymous city a "warm island," influenced by mild Atlantic air in winter and continental-and sometimes subtropical air-in summer" (G 54). Jurgoński introduces slightly different meanings, contained in the metaphor of the city-island, when he writes about "a green island nestled in greenery" (ME 55). This periphrasis, which metonymically appeals to the forests surrounding the city, has additional connotations: the toponym Zieleń-the name of Zielona Góra in Jurgoński's poem-alludes to the term Thalloris (Gr. "becoming green"), first used by Joachim Grisbeck. The German poet coined this name from the color of the vine that covers the city hills.

According to historical records, grapevine began to be grown in the area of today's Zielona Góra at the beginning of the thirteenth century, while archaeological research indicates that the birth of local winemaking can be dated back to the tenth century. In literary terms, however, these findings are of little significance. The basis of the idealized image in the cited works is the belief in 
the eternal coexistence of the city and the vine. That is why the stories about the origin of City of Wine usually link its genesis with the founding of the first vineyard. The author of Enographia mistyczna (Mystical Enographia) goes even further and connects the founding act of the town with the divine work of creatio mundi. In the biblical plan that Kuleba invokes, the grapevine is the most important plant that appeared on earth on the third day of Creation, and the work on the vineyard is the beginning and foundation of all other human activity. The combination of both orders - the human and the divine-justifies the sense of the existence of a place and guarantees its duration:

Centuries passed. The city persisted over time, grew, the cobblestones extended further and further. People cut down pine forests to make room for new construction sites and vineyards. The vineyards produce wine, which the town nurtured in the deep cellars of the houses. The history of the place was written by the years of harvests and disasters, late frosts and early frosts, hot autumns dripping with sweet must and rainy Junes, heralding poor crops. Time was measured by the hourly tolling of bells on that September or October morning when all the townspeople were summoned to the wine-making festival. (EM 733)

The duration in time referred to in the quoted passage is also based on other premises. By stating that the history of a place is written by atmospheric phenomena, disasters, and harvests, Kuleba not only suspends the passage of time, but also frees the place from the order of history and subjects it to the laws of nature.

Winescape, which is a type of agricultural landscape, rusticizes the urban space and gives it the characteristics of a rural landscape; within it the processes of urbanization are subordinated to the vegetative cycle of nature. This is what happens in the novel Grünberg, where the image of a place is different than in Kuleba's work: in reference to the way a vine grows, spreading spontaneously like a creeper, and conquering the surrounding area. Fedorowicz's city is a monstrous plant that grows through the expanding vine-like branches and lives its own life as an independent ecosystem, not subject to human control:

Vineyards creep into fields and woods south of downtown, west, southwest, north, and northeast, and east. They go in, out into the world through slopes and mountains, they spread across valleys and plateaus. They grow, they rush uncontrollably, as if the head gardener had 
forgotten to prune and break off the young shoots, as if he had consciously experimented, allowed the elements to provide the city with eternal life, which dwells in permanent autumn. (G 49)

The grapevines penetrate the fabric of the city, shape its topography and organize its spatial structure. Fedorowicz compares this structure to an oak tree: the central part of Grünberg, described in the novel, which is "free of vines" (G 49) is like a tree trunk, while the roads branching out of the center, where the vineyards are located, are like branches and boughs, covered with green plants. This metaphor illustrates the rapid, healthy growth of the pre-war vitis vinifera, which is indestructible because it is set on a city foundation as durable and strong as an oak tree.

Jurgoński bases the image of post-war Zielona Góra on a similar parallel between the tree and the city. The author of Mniejsza Epopeja (The Minor Epic) describes urban architecture by comparing "the ribbons of streets" with tight circles of tree rings surrounding the core of a tree. This is a second-degree comparison, following the earlier Homeric simile, in which the object of comparison is Vine Hill, treated as the focal point of the city, and the compared is "a huge barrel, half dug into the ground, / in which fresh wine's sparkling foam / boils and bubbles with youth" (ME 55). In this variant, the city is no longer a rhizomatically growing plant, but-in accordance with the convention of the poem, which mainly uses the panoramic perspective (view from above) -an organized biocultural structure, reflecting "the general condition of the spiritpeople, houses, and streets in a common organism" (ME 74).

All of these conceptualizations, although expressed in different poetic styles, conceive of winescape as a space of coexistence between nature and culture, within which the city and the vine are inseparably intertwined. "It is hard to imagine that one could exist without the other" (WM 109), says Mąkosa's protagonist. Yet what is unimaginable to Matylda, a German woman of Slavic origin, turns out to be an immanent feature of the place, a principle that organizes the imaginative geography of postwar Zielona Góra. The juxtaposition of the idealized vision of culture-nature with reality is bound up with the narrative intention of this prose: the purpose of highlighting the contrast is to strengthen the image of destruction after the war.

If we consider these works together and order the city space shown in them (its transformations) according to chronology, we can trace the successive stages of the destructive process. The opening moment is marked by the year 1945, when-as Fedorowicz shows-vineyards are trampled by Soviet tanks, 
and then destroyed by the tractors of Polish settlers who pluck out the vines to plant potatoes in their place. Fifteen years after this event, in 1960, the year referred to in Jurgoński's and Markiewicz's retrospectives, there are almost no crops in Zielona Góra. Single bushes can be found in only two places: at the Winiarka monument in the market square ("A few solitary bushes were symbolically planted at the feet of the patroness of the grape harvest" NM 134) and on Winne Wzgórze near the Palm House. ("Those from under the Palm House," says the narrator, "were methodically dug up even during martial law.") The sculpture of Winiarka and the "Winne Wzgórze" (Wine Hill) toponym evoked by Markiewicz are surrogates of the pre-war tradition. The most telling symptom of the degradation of winemaking, however, is the Grape Harvest, during which not wine but beer is poured into glasses. This substitution is shown by Mąkosa in the description of the postwar festivities and by Markiewicz, who sets the plot of his novel during the Vine Harvest celebration taking place almost half a century later. The propaganda character (Mąkosa) and the country fair atmosphere (Markiewicz) of the grape harvest festivities expose the arbitrariness of the holiday, which remains a "wine harvest celebration" in name only.

The obliteration of winescape, which is narrated using the rhetoric of decline, can be seen in a twofold way: in terms of ecological catastrophe and social destruction. Natural and social processes overlap, and the use of the metaphor of uprooting expresses this interference. This applies both to the inhabitants (displaced Germans and displaced Poles) and to the landscape, shown as "a mutilated, uprooted landscape" (G 135). The motif of "concreting over" also fits into the narrative that speaks of destruction: "On the hills, instead of vineyards, there are multi-storey houses made of concrete, in the forests-garbage dumps, a new cemetery with an area the size of the old town" (G 135-136); this is how Fedorowicz characterizes contemporary Zielona Góra. In Markiewicz's work, Lisia Street is the synecdoche of the city, where high-rise buildings were erected on what used to be a meadow.

Against this backdrop, the exchange of meanings ascribed to the sour wine grapes, emblematic of the place, is significant. In pre-war couplets, this motif was a component of humorous narration (the wine called Grünberger was ridiculed especially often, which Mąkosa alludes to in the comparison: "When a woman has worries, she is as sour as grünberger" (WM 241). In contemporary prose, the acidity and astringency of the Zielona Góra fruit becomes a metonymy of the depreciation of the place. Jurgoński calls the city "a green island nestled in greenness, / that bore little sour grapes" (ME 55). Markiewicz goes even further and questions the earlier winemaking tradition by stating that "The grapes from 
Zielona Góra have always been sour and good for nothing. Even the cuttings brought from the south of France, when ripening on the local hills, did not acquire the noble, western-southern sweetness" (NM 135).

One of the essential features of the cultural landscape is the mediating causal relation that is activated within it, which is expressed in the participatory, interactive relationship between the subject-being-in-the-world and the world. This causality often remains invisible; "It itself and its constitutive meaning are revealed only when," writes Ryszard Nycz, "the cultural landscape disappears, transforms, falls into ruin, and is reconstructed only from material traces and vestiges" (Nycz 95). This is precisely the situation we are dealing with in the novels in question. Although each of them projects the relation between the bio- and socio-spheres in a slightly different way, each shows the process of destruction, which ensues from breaking the continuity of wine-making traditions and disregarding the legacy of previous generations.

In response to this process, enographic narratives act as pathways, which, according to Tilley, order the experience of the places that they connect, thus linking accumulated memories to place, and providing "spatial knowledge." In this way, they become "obvious templates for future movements and the maintenance of relationships" (Tilley 31) and are conducive to reinhabitation.

Reinhabitation, a concept introduced by Peter Berg and Raymond Dasmann (Berg, Dasmann 217) as one of the key slogans of the bioregionalism, a philosophy that they pioneered, has an ecological slant and means, broadly speaking, learning to live in a place that was devastated ("disrupted and injured") by exploitation in the past. In the case of the Zielona Góra winescape, the definition should be expanded, as it refers to a situation in which a place is destroyed by non-exploitation or by improper exploitation, such as the one depicted by Fedorowicz:

The new inhabitants have a barbaric attitude towards wine. They pick the grapes when they become discolored or soft, put them in jugs, add water and pour sugar on top. After fermentation they drink the wine quickly. They do not care for the vines; they believe that the fuller vine and the more grapes, the better. ( $\left.\mathrm{G} 24_{2}\right)$

Literary works can serve a reinhabitative function in many ways: they can participate in commemorating "concreted" landscapes or devastated species; 
introduce current residents to long-forgotten stories about a place or provide new stories about it; and design the future by demonstrating a compatible coexistence of people and the environment (Welling 118). Sorenella Iovino refers to this type of literature as reinhabitation narratives and defines these narratives as a type of cultural-educational practice that involves restoring the "ecological imagination" to places through working with local stories (Iovino 106). The works discussed here also fall within this formula. The restoration of the "ecological imagination" depends on three revitalization strategies: appealing to the "wine landscape" as a space determined by the laws of nature (1), activating the bio-memory inscribed in the oenographic biotopos (2), and reactivating the winescape with the help of the senses (3).

(1) The first strategy hinges on the assumption that reinhabitation is inherent in the rural-agrarian character of winescape and, therefore, can happen spontaneously, based on the natural laws of nature and independent of human actions. The "wine landscape" is like a living plant, subject to a cyclical process of rebirth, and thanks to the forces of nature, analogous to the vital forces that bring the protagonist of Winne Miasto (The Wine City) "back to life" - it is susceptible to self-regeneration. The message of Fedorowicz's novel rests on this idea:

When aliens destroy this world, one way or another, sooner or later, they will have to rediscover it, dig it out from the ruins and ashes, restore it. In a hundred years, the vineyards will be reborn and produce the kind of fruit that they produce now and that they produced a thousand years before. The böchmischer, traminer, and white burgundy will return to their place, and again guardian spirits, angels, and people will guard these places with their lives. ( $\mathrm{G} 2 \mathrm{O}-21)$

In Grünberg's novel, the self-renewing mechanism of nature also finds explanation in the Nietzschean idea of eternal returns. The wheel of life is set on the "axis of Grünberg" ( $G$ 55), that is wine. Despite the transformations of the environment, whatever constitutes the essence of winescape remains unchanged, and Zielona Góra is periphrastically called "the city of permanent autumn" ( $G$ 135-136). In the world depicted in the novel, the recurrence is emphasized through the spatio-temporal order and the construction of the protagonists: in the first part of the novel they are German residents of Grünberg, Milena and Ernst, whereas in the last part they are Polish residents of Zielona Góra, Milena and Ernest. The vineyard which they own transmits the past: "I feel as if we had set up this vineyard years ago, and now we're doing it all over again," says Ernest, and adds that it is not a vague and disturbing sense of déjà vu, connected with 
the circle of eternal returns, but "certainty and memory," actualized through a cycle of repetitions. The image of the city rooted in such a temporal-spatial structure becomes part of a retroactive and, at the same time, prospective utopia: the place appears to our eyes an enduring, indestructible winescape.

(2) The return of "böhmischer" and "traminer" mentioned by Fedorowicz is facilitated by means of vegetative propagation of the vine. This type of cultivation makes it possible to maintain the same grape varieties with the same genome, over and over again for thousands of years. Therefore, the hero, when finding a graft of the traminer, asks: "Do you think we'll be able to propagate it, that we'll know what the wine from Grünberg tasted like?" (G 133). The author of Enografia Mistyczna (Mystical Enography) is guided by a similar principle of recreating a crop on the basis of the genetic code of a found plant. In the essay "Spätburgunder," Kuleba writes that "single vines of Spätburgunder, today known worldwide as pinot noir, have survived from former non-German plantings" (EM 751), and in the "Blauer Schönedel" essay, he reports the discovery of an ancient "incomprehensibly vigorous" specimen of Blauer Schönedel in a Zielona Góra mountain village. The author calls it "the last relic holding onto a crumbling brick wall" (EM 727 ).

The surviving species are carriers of bio-memory. Elżbieta Rybicka, who introduced the concept of bio-memory to Polish literary studies, writes that the vegetation of some areas creates "not only natural heritage, but also cultural memory" (Rybicka 485). However, the memory of wine has its own special characteristics and can be understood in different ways. In the most popular meaning, it means "the memory of a vineyard in bloom, written down in some mysterious way, imprinted in the genetic code of a plant and its fruit, and then still lasting in the living organism of wine. Living as long as the wine lives" (EM, Koscheberger 745).

In Enografia Mistyczna (Mystical Enography), the memorative relationship between wine and place is also actualized through the topos of the underground city. The Zielona Góra from the past has disappeared, gone underground, into the darkness "still imbued with the distant scent of wine" (ET 725), and the contemporary city that has risen on the surface draws from it like a plant feeding on the sap of the earth. Each of Kuleba's essays tells the story of a different species of local wine that is closely associated with a particular region of Zielona Gora. In this way, phytonyms become toponyms: landmarks of urban topography reconstructed on the plan of a underground city and then mapped on the surface. The names of winescapes contain the cumulative history of the place and indicate paths connecting the past with the present. 
(3) Characteristically, winescape is experienced not only visually, but also in an olfactory (as smellscape) and gustatory way (as tastescape). Taste and smell, the main components of wine, differentiate and individualize the "wine landscape," often associated with the grapevine strain dominating in a given area. In the case of Zielona Góra, such a strain is the traminer, which produces "the noblest of Zielona Góra's white wine varieties" (EM 743), according to Kulba. Fedorowicz speaks of this strain in sacral overtones: "It is not just any wine, but the sanctum vinum, the salt of the earth, the axis of Grünberg" (G 55). In both authors, we also find an olfactory description of the traminer, a grape which has "either greenish-white, pink or dark pink fruit, but always a mossy aroma" (EM 743 ) and "aromas of wild rose, citrus and a touch of ginger" (G 134). And it is the traminer that constitutes the terroir of Zielona Góra and the surrounding area.

Terroir, usually referring to the specific crops representative of a region and the product allied with them, transmits the customs and values that define a community (Bassett 104). In doing so, it actualizes the past. "Today there are no more vineyards in town. But to an explorer, steeped in the mysteries of the physiology of taste, it is not difficult to imagine an era of splendor, condensed into the inspired atmosphere of a lavishly set table" (EM 733), writes Kuleba. "The ever-ripe fruit of the traminer, the böhmischer, and crimson grape" (G 39) also reactivates the memory of place. Fedorowicz evokes terroir when he asks about the taste of wine, in which different features of the winescape intermingle: "in the glass, will we find a chestnut avenue and a rapid stream at the foot of the hill, pine forests behind the vineyard" (G 134).

As components of winescape, taste and smell stimulate regeneration. By penetrating beyond the material palpability into the realm of the intangible and extending beyond visual perception, they allow us to recover the hidden qualities of a place: to enter "the darkness, still infused with the distant scent of wine that has been seeping into the brick walls for hundreds of years" (EM 725). Winescape viewed in terms of smellscape displaces the image of Zielona Góra as a city of tart and sour grapes, as shown by Jurgoński and Markiewicz. This is what happens at the end of their texts. The first author, in the conclusion of the poem, conjures the image of a chalice, which is a metonymy for wine: "In the golden chalice of autumn Green overflows" (EM 85). Markiewicz, in turn, in the last chapter of his novel, writes about the "greenish-moist smell of a meadow" and shows that the "bleak spatial landscape with geometric irregularities" conceals (this is yet another version of the underground city) the possibility of another space: 
Maybe somewhere between these schematic contours, maybe even in the middle, there was a meadow. Concreted over, asphalted over, overexposed with neon lights-but alive, taking revenge on the foundations of a new world. (NM 156)

One of the causes of the contemporary crisis of imagination at the root of the environmental crisis, says Rybicka, is the imbalance between the macroperspective of global processes and the microperspective of local ones (Rybicka 488). In the broad horizon of ecological threats, the researcher notes, natural environments located in specific places disappear from sight. Thus, "we have not only a strongly awakened ecological awareness, but also equally strongly deepened ecological unawareness encompassing the ability to recognize local plant and bird species, the knowledge of the existence of underground rivers flowing through our cities, or the history of reforestation of what previously were mountainous meadows" (Rybicka 488).

Contemporary Zielona Góra prose, which reminds us of the existence of familiar varieties of local vines and teaches us about the nature and history of the local environment, undoubtedly stimulates ecological awareness. However, given the aforementioned "crisis of imagination," its performative qualities related to restoring "ecological imagination" to places are more important than educational and cognitive functions.

The literary works which I have discussed in this article can be classified in many ways: as belated founding stories, "collective texts", post-settlement narratives, or eno-graphic narratives. From an environmental-local perspective, they are primarily a tool of reinhabitation. As reinhabitation narratives, they revive the cultural and ecological possibilities of place and create them, as it were, anew, restoring the relationship between the world of humans and of "non-human" beings, recovering the lost bond between the bio- and sociosphere. From another point of view, they instaurate the place by reactivating winescape in its memorative (wine-memoryscpe) and causal (wine-taskscape) dimensions. ${ }^{5}$

One of the properties of reinhabitation narratives is that, as narratives-in-action, they have no ending; they are characterized by "open-endedness," in the

5 Literary reinhabitation narratives are part of a wider process of recovery of Zielona Góra's "winescape" after 1989. This process is stimulated by many different factors and would not be so effective without postwar cultivation of local wine traditions by the annual Grape Harvest Festival and the winemaking exhibition in the Lubuskie Museum. 
words of Iovino. The researcher refers to them as "anti-epic" (Iovino 107) and writes that unlike the epic, which is a stable re-presentation that is frozen in an unchanging destiny, the "anti-epic" is defined by mobility, flexibility, and openness. In literature on Zielona Góra, this distinction takes on additional meanings, as we must recall the postwar demand for an epic that would speak of the settlement of the western lands. Such an epic never came into being, and it was only years later that prose appeared-a "lesser epic," as it might be called using the title of Jurgoński's poem-that successfully tackled the subject of the development of the post-German territories, approaching it not from the perspective of politics but from that of ecological humanities (Domańska 13-32). Through reinhabitation narratives, which as "anti-epic" tell stories about people and places, the past, even that which has been tabooed for many years, is reopened, and so is the future.

Translated by Marcin Tereszewski

\section{| Works cited}

Alampi, Sottini Veronica, Barbierato Elena, and Bernetti Iacopo, et al. "Winescape Perception and Big Data Analysis: An Assessment Through Social Media Photographs in the Chianti Classico Region.” Wine Economics and Policy 8.2 (December 2019): 127-149.

Bassett, Thomas J., et al. "Constructing Locality: The Terroir Approach in West Africa." Africa: Journal of the International African Institute 77.1 (2007): 104-129.

Berg, Peter and Dasmann Raymond. "Reinhabiting California." Reinhabiting a Separate Country: A Bioregional Anthology of Northern California. Ed. Peter Berg. San Francisco: Planet Drum, 1978. 217-220.

“Diabeł, wino i rycerz." Złota dzida Bolesława. Podania, legendy i baśnie Ziemi Lubuskiej. Ed. Janusz Koniusz. Poznań: Wydawnictwo Poznańskie, 1970. 189-192.

Domańska, Ewa. "Humanistyka ekologiczna." Teksty Drugie 1.2 (2013): 13-32.

Dylewska, Agnieszka. “Topos winorośli i Lasu Odrzańskiego w tekstach poetyckich na łamach Grünberger Hauskalendar.” Lubuski Palimpsest. Ed. Marta J. Bąkiewicz. Zielona Góra: Oficyna Wydawnictwa Uniwersytetu Zielonogórskiego, 2017. Historia Literatury Pogranicza, vol. 6. 121-147.

Erll, Astrid. "Literatura jako medium pamięci zbiorowej." Pamięć zbiorowa i kulturowa. Wspótczesna perspektywa niemiecka. Trans. Mariusz Saryusz-Wolska. Ed. Mariusz Saryusz-Wolskiej. Kraków: TAiWPN Universitas, 2009. 234-247. 
Fedorowicz Krzysztof, Grünberg. Kraków: Wydawnictwo Libron, 2012.

Gieba, Kamila. "Regionalna geopoetyka poniemieckiego miasta. Przypadek współczesnej prozy Ziemi Lubuskiej.” Nowe poetyki miejskie: Z problematyki urbanistycznej w literaturze XX i XXI wieku. Eds. Magdalena. Roszczynialska and Katarzyna Wądolny-Tatar. Kraków: Wydawnictwa Naukowe Uniwersytetu Pegagogicznego Kraków, 2015. 183-190.

Gieba, Kamila. "Die kulturelle Landschaft der Region und ihr Wandel in der Lebuser Nachkriegsprosa." An der mittleren Oder: Eine Kulturlandschaft im deutsch-polnischen Grenzraum, Ed. Marta J. Bąkiewicz. Paderborn: Ferdinang Schöningh, 2016. 158-170.

Gieba, Kamila. “(Nie)pamięć wielokulturowości w literaturze o przesiedleniach na Ziemie Zachodnie.” Porównania 2.21 (2017): 79-89.

Gieba, Kamila. “Tradycje winiarskie w literaturze lubuskiej w kontekście regionalnej polityki miejsca." In Gremium. Studia nad Historia, Kulturą i Polityka 13 (2019): 209-216.

Ingold, Timothy. "Czasowość krajobrazu.” Krajobrazy. Antologia tekstów. Trans.

B. Frydryczak. Eds. Dorota Angutek and Beata Frydryczak. Poznań: Wydawnictwo Poznańskiego Towarzystwa Przyjaciół Nauk, 2014. Krajobrazy, vol. 3. 141-164.

Iovino, Serenella. "Restoring the Imagination of Place: Narrative Reinhabitation and the Po Valley." The Bioregional imagination. Literature, Ecology, and Place. Eds. Tom Lynch, Cheryll Glotfelty, and Klara Armbruster. Georgia: University of Georgia Press, 2012. 100-117.

Johnson, Ray and Johan Bruwer. "Regional Brand Image and Perceived Wine Quality: The Consumer Perspective." International Journal of Wine Business Research 19(4) (November 2007): 276-297.

Jurgoński, Marek. Mniejsza epopeja. Zielona Góra: Towarzystwo Miłośników Zielonej Góry, 2014.

Kajan, Tadeusz. “Zielona Góra - miasto nowe." Odzyskane gniazda. Proza i poezja o Ziemi Lubuskiej. Ed. Eugeniusz Paukszta, Poznań: Wydawnictwo Poznańskie, 1963. 330-332.

Kuleba, Mirosław. “Enografia mistyczna.” Enographia Thalloris. Ed. Mirosław Kuleba. Zielona Góra: Fundacja Gloria Monte Verde, 2013. 723-777.

Leszkowicz-Baczyński, Jerzy. "Fenomen współczesnego winiarstwa w Polsce. Kulturowe, społeczne i ekonomiczno-prawne aspekty winiarstwa." Winiarska i bachiczna tradycja Zielonej Góry. Studia i szkice społeczno-kulturowe. Eds. Dorota Angutek, Artur Kinal, Jerzy Leszkowicz-Baczyński, et al. Zielona Góra: Oficyna Wydawnicza Epigram, 2019. 237-304.

Markiewicz, Czesław. Niewinne Miasto, Poznań-Zielona Góra: Stowarzyszenie Producentów i Dziennikarzy Radiowych, 2003. 
Mąkosa, Zofia. Wendyjska Winnica: Winne miasto. Poznań-Wrocław: Książnica, 2019.

Mikołajczak, Małgorzata. "Nowa (?) regionalna tożsamość. Przemiany pamięci w twórczości lubuskich poetów." Opcja niemiecka: O problemach $z$ tożsamością i historią w literaturze polskiej i niemieckiej po 1989 roku. Eds. Wojciech Browarny and Monika Wolting. Kraków: Uniwersitas, 2014. 35-47.

Mikołajczak, Małgorzata. "Die kulturelle Landschaft der Region in der Lebuser Poesie." An der mittleren Oder: Eine Kulturlandschaft im deutsch-polnischen Grenzraum. Ed. Marta Jadwiga Bąkiewicz. Paderborn: Ferdinang Schöningh, 2016a. 137-157.

Mikołajczak, Małgorzata. "Do czego literaturze regionalnej potrzebny jest Niemiec? (na przykładzie twórczości lubuskiej).” Teksty Drugie 3 (2016b): 251-272.

Nycz, Ryszard. “Percepcja w działaniu. Casus krajobrazu kulturowego.” Kultura jako czasownik. Sondowanie nowej humanistyki. Warszawa: Instytut Badań Literackich PAN, 2017. 83-96.

Petras, Paul. "Kennst du die Stadt [Znasz-li to miasto].” In: “Topos winorośli i Lasu Odrzańskiego w tekstach poetyckich na łamach Grünberger Hauskalendar.” Lubuski Palimpsest. Trans. Agnieszka Dylewska. Ed. Marta J. Bąkiewicz. Zielona Góra: Oficyna Wydawnictwa Uniwersytetu Zielonogórskiego, 2017. Historia Literatury Pogranicza, vol. 6. 134.

Rybicka, Elżbieta. "Biopamięć (pomiędzy etnobotaniką a bioregionalizmem)." Regionalizm literacki-historia i pamięć. Eds. Zbigniew Chojnowski and Elżbieta Rybicka. Kraków: Kraków Uniwersitas, 2017. 484-498.

Tilley, Christopher. A Phenomenology of Landscape: Places, Paths and Monuments. Oxford/Providence: Berg Publishers, 1994.

Welling, Bart. “'This Is What Matters.' Reinhabitory Discourse and the 'Poetics of Responsibility' in the Work of Janisse Ray." The Bioregional Imagination. Literature, Ecology, and Place. Eds. Tom Lynch, Cheryll Glotfelty, and Klara Armbruster. Georgia: University of Georgia Press, 2012. 118-131.

\section{| Abstract}

MaŁgorzata MikoŁajCzak

Winescape: Local Reinhabitation Narratives (the Case of Zielona Góra)

Reinhabitation narratives are cultural-educational practices that involve restoring the "ecological imagination" of places through stories associated with them. The 
term proposed by Serenella Iovino in the field of bioregional studies, which refers to places disrupted and injured by exploitation, is applied to contemporary stories about Zielona Góra. The author shows how, in reference to the city's German past, these stories reactivate its wine tradition and project the winescape as a taskscape (in Timothy Ingold's sense). Under consideration are both the effects of the destruction of the pre-war heritage (in natural and social terms) and regeneration, which is accomplished through three strategies: appealing to the winescape as a space determined by the laws of nature (1), activating the bio-memory inscribed in the enographic biotopos (2), and reactivating the winescape through sensory experience (3). Responding to the contemporary crisis of ecological imagination, local reinhabitation narratives instantiate place and revive its cultural and ecological possibilities. They constitute an "anti-epic" that opens up the past and the future.

Keywords: winescape, reinhabitation, contemporary Zielona Góra prose, reinhabitation narrative

\section{| Abstrakt \\ MaŁgorzata MikoŁajCzaK \\ Winescape: lokalne narracje reinhabitacyjne (przypadek Zielonej Góry)}

Narracje reinhabitacyjne to praktyki kulturowo-edukacyjne, które polegają na przywracaniu „ekologicznej wyobraźni” miejscom poprzez pracę z odnoszącymi się do nich historiami. Termin, który na gruncie badań bioregionalnych zaproponowała Serenella Iovino, a który dotyczy miejsc wyniszczonych (disrupted and injured) przez eksploatację, zostaje odniesiony do współczesnych opowieści o Zielonej Górze. Autorka pokazuje, jak w nawiązaniu do niemieckiej przeszłości miasta opowieści te reaktywują jego winiarską tradycję i projektują winescape ('winny krajobraz') jako taskscape ('przestrzeń zadaną' w rozumieniu Timothy Ingolda). Chodzi zarówno o skutki zniszczenia przedwojennego dziedzictwa (w wymiarze przyrodniczym i społecznym), jak i rewitalizację, która dokonuje się poprzez trzy strategie: apelowanie do „winnego krajobrazu” jako do przestrzeni zdeterminowanej prawami przyrody (1), uruchamianie biopamięci wpisanej w enograficzny biotopos (2) i reaktywowanie winescape za pomocą odczuć zmysłowych (3). Lokalne narracje reinhabitacyjne, będące odpowiedzią na współczesny kryzys wyobraźni ekologicznej, instaurują miejsce i ożywiają jego kulturowe i ekologiczne możliwości. Stanowią „antyepos” otwierający przeszłość i przyszłość. 
Słowa kluczowe: winescape, reinhabitacja, współczesna proza zielonogórska, narracja reinhabitacyjna

\section{| About the Author}

Małgorzata Mikołajczak - Professor, Head of the Literary Studies Department at the Institute of Polish Philology of the University of Zielona Góra, member of the Committee on Literary Studies at the Polish Academy of Sciences, author of monographs on the poetry of Urszula Kozioł and Zbigniew Herbert, scientific editor of the New Regionalism in Literary Studies series. Her research interests include literary theory, contemporary literature and regionalism in literary studies. E-mail: M.Mikolajczak@ifp.uz.zgora.pl

ORCID: 00oo-0002-7570-581X 